\title{
Çocukluk Çağı Kronik Hastalıklarında Tıbbi Beslenme Tedavisi Bağırsak Mikrobiyotasını Etkiler mi?
}

\author{
Does Medical Nutrition Therapy Affect Gut Microbiota in Childhood Chronic Diseases?
}

\author{
Sevde Mercan ${ }^{1}$, Hülya Gökmen Özel ${ }^{2}$
}

Geliş tarihi/Received: 16.11.2019 • Kabul tarihi/Accepted: 30.12.2019

\section{ÖZET}

Sağlıklı bağırsak mikrobiyotası patojenlerden korunma ve immün yanıtların olgunlaşması dahil olmak üzere pek çok açıdan konakçıya fayda sağlamaktadır. Ortaya çıkan kanıtlar, bağırsak mikrobiyotasının alerjik hastalıklar, çölyak, tip 1 diyabet ve obezite gibi erişkinlikte de devam edebilen çocukluk çağı hastalıklarının gelişimi ile ilişkili olduğunu göstermektedir. Beslenme, bağırsak mikrobiyota çeşitliliğini ve işlevselliğini etkileyen ana çevresel faktör olarak kabul edilmektedir. Diyetin kısa sürede bağırsak mikrobiyotasında önemli değişikliklere yol açabileceği gösterilmiştir. Bu doğrultuda çocukluk çağı kronik hastalıklarında tıbbi beslenme tedavisi uygulamalarının da bağırsak mikrobiyota bileşimini etkileyeceği düşünülmektedir. Beslenme tedavileri ve bağırsak mikrobiyotası arasındaki ilişkiyi ve etkileşimleri anlamak, hastalıkların yönetimi için kritik öneme sahiptir. Bu derlemede, çocukluk çağındaki bazı kronik hastalıklarda uygulanan tıbbi beslenme tedavilerinin bağırsak mikrobiyotası üzerindeki etkileri incelenmiştir.

Anahtar kelimeler: Çocukluk çağı kronik hastalıkları, bağırrsak mikrobiyotasl, tıbbi beslenme tedavisi

\begin{abstract}
A healthy gut microbiota benefits the host in many respects, including protection from pathogens and maturation of immune responses. The emerging evidence shows that intestinal microbiota is associated with the development of childhood diseases such as allergic diseases, celiac, type 1 diabetes and obesity. Nutrition is considered to be the main environmental factor affecting the diversity and functionality of the gut microbiota. Diet has been shown to cause significant changes in the intestinal microbiota in a short time. In this respect, it is thought that medical nutritional therapy in childhood chronic diseases will affect the intestinal microbiota composition. Understanding the relationship and interactions between nutritional therapies and intestinal microbiota is critical to disease management. In this review, the effects of medical nutritional therapies on intestinal microbiota in some childhood chronic diseases are examined.
\end{abstract}

Keywords: Childhood chronic diseases, gut microbiota, medical nutrition therapy

\section{Gíriş}

Son on yllda, insan bağırsak mikrobiyotasına olan ilgi çarpıcı bir biçimde artmaktadır. Bilimsel kanıtlar, bağırsak mikrobiyotasının sağlığın sürdürülmesi ile

\footnotetext{
1. Diyetisyen, Ankara, Türkiye

(D) https://orcid.org/0000-0002-5374-6741
}

ilişkili olduğuna işaret etmektedir. Erken yaşamda bağırsak mikrobiyotasının uygun şekilde gelişimi yaşam boyu sağlık için önemlidir (1). Çocukluk

2. İletişim/Correspondence: Hacettepe Üniversitesi Sağllk Bilimleri Fakültesi Beslenme ve Diyetetik Bölümü, Ankara, Türkiye

E-posta: hgokmen@hacettepe.edu.tr • • $\odot$ https://orcid.org/0000-0002-8282-6468 
çağında görülen bazı bulaşıcı olmayan kronik hastalıklarm tedavisinde tıbbi beslenme tedavisi önemli yer tutmaktadır ve bu beslenme tedavileri hastalar için birincil veya yardımcı tedaviler olarak kabul edilmektedir. Glutensiz diyet, ketojenik diyet, düşük fenilalanin içeren diyet hastalıklarda önerilen beslenme tedavilerinden bazılarıdır. Hastalık semptomları üzerinde yararlı etkiler gösteren bu beslenme tedavileri, özellikle uzun süreli uygulanmaları durumunda bağırsak mikrobiyota bileşimini etkileyebilir (2). Bu derleme makalenin amacı, çocukluk çağındaki bazı immün aracılı, metabolik ve nörolojik hastalıklarda uygulanan tıbbi beslenme tedavilerinin bağırsak mikrobiyotası üzerindeki etkilerinin incelenmesidir.

\section{Besin Alerjileri}

Besin alerjisi, vücudun bağışıklık sisteminin belirli bir besine karşı geliştirdiği anormal bağışıklık yanıtından kaynaklanan reaksiyonlar olarak tanımlanmaktadır (3). Alerjik yanıt, antijenlere karşı immün toleransin bozulmasindan kaynaklanmaktadır. Bağırsak mikrobiyotası, bağışıklık sisteminin besin antijenleriyle reaksiyona girmesini önleyen immün tolerans gelişiminde önemlidir (3). Bağırsak mikrobiyotasındaki disbiyozis, mukozal immünolojik toleransin bozulmasina ve alerjik yanita neden olmaktadır (4). Beslenme ve besin alerjisi ilişkisini inceleyen bir çalışma, ilk iki yaştaki beslenme alışkanlıklarının besin alerjisi gelişimini etkilediğini göstermiştir (5). Yüksek düzeyde meyve, sebze ve evde hazırlanan yiyeceklerden oluşan bir bebek diyetinin besin alerjileri ile daha az ilişkili olduğu gösterilmiştir (5). Yüksek lifli diyetin, Bifidobacterium gibi diyet liflerini fermente edebilen bakterilerin üremesini artırarak kısa zincirli yağ asitleri (KZYA) seviyelerinde bir artış sağladığı bilinmektedir (6). Özellikle Bifidobacterium'un azalan seviyeleri, alerji riskinin artmasıyla ilişkilidir (6).

Besin alerjilerinin tedavisinde ilk aşama sorumlu besinlerin belirli süreyle diyetten tamamen çıkarılmasıdır. Örneğin, inek sütü proteini alerjisi tedavisinde inek sütü ve ürünleri diyetten çıkarılır ve anne sütü, yoğun şekilde hidrolize edilmiş kazein içeren formulalar veya gerekirse aminoasit bazlı formulalar kullanılır (7). Kullanılan bebek Formulalarının bağırsak mikrobiyal bileşimine etkisini değerlendirmek amacıyla yapılan bir çalışmada, yoğun şekilde hidrolize edilmiş kazein içeren bebek formulasının in vitro kolon modelinde mikrobiyota bileşimini etkilediği ve bütirat üretimini artırdığı gösterilmiştir (8).

\section{İnflamatuvar Bağırsak Hastalığı}

İnflamatuvar bağırsak hastalığı (İBH), nedeni tam anlaşılamamış aktivasyon ve remisyonlarla seyreden kronik bağırsak hastalıklarını tanımlamak için kullanılan bir terimdir (9). Hastalığın en sık görülen iki formu Crohn hastalığı $(\mathrm{CH})$ ve ülseratif kolittir (ÜK). Konakçı genetiği, mukozal bağışıklık sistemi ve enterik bakteriler arasındaki karmaşık etkileşimlerin İBH gelişiminde rol oynadığı düşünülmektedir (10). İBH'da disbiyozis sonucu istilacı bakterilerdeki artış koruyucu bakterilerdeki bir azalışla birleştiğinde, mukozal geçirgenliğin artması ve immünolojik toleransın kaybı ile sonuçlandığı tahmin edilmektedir (9). CH ve ÜK olan çocukların fekal mikrobiyotasının sağlıklı kontrollerle karşılaştırıldığı bir çalışmada, CH'de Faecalibacterium, Bacteroides ve Bifidobacteria sayısının ve fekal mikrobiyota çeşitliliğinin azaldığı ve Escherichia coli (E. coli) sayısının arttığı; ÜK hastalarında ise aktif durumdayken Bifidobacteria sayısında bir azalma olduğu saptanmıştır (10).

Avrupa Pediatrik Gastroenteroloji, Hepatoloji ve Beslenme Derneği (European Society for Paediatric Gastroenterology, Hepatology and Nutrition [ESPGHAN]), $\mathrm{CH}$ olan çocuklarda remisyonun sağlanması için tek başına enteral beslenmeyi (EB) birincil tedavi olarak önermektedir (11). EB tedavi protokolü, genelikle 6-8 hafta boyunca besin alımını dışlayarak enerji gereksinmesinin \%100’ünü sağlamak için enteral ürün (elemental, semi-elemental ve polimerik ürünler) verilmesini içerir. EB tedavisinin yararlarına rağmen, bağırsak mikrobiyotasının yapısı ve fonksiyonel etkinliği üzerindeki etkisine ilişkin veriler sınırlıdır. Yapılan 
bir çalışmada hastalık belirtilerindeki iyileşmeye rağmen $\mathrm{CH}$ olan çocuklarda, EB’nin bağırsak mikrobiyota çeşitliliğini, Faecalibacterium prausnitzii ve bütirik asit düzeylerini azalttığı görülmüştür (12). EN sirasinda azalan KZYA üretimi, kısmen kullanılan EB ürünün posa içermemesi ya da düşük posalı olması ile açıklanabilir. EB'nin hastalık belirtileri üzerindeki yararlı etkilerinin ve bağırsak mikrobiyotasında meydana getirdiği değişikliklerin, EB içeriğinin doğrudan bir sonucu olup olmadığı daha fazla araştırılmayı gerektirmektedir. Literatürde çocuklarda ülseratif kolit için geçerli bir beslenme tedavisine ve bunun mikrobiyotaya olan etkilerine yönelik çalışma bulunamamıştır.

\section{Çölyak Hastalığı}

Çölyak hastalığı, genetik olarak duyarlı bireylerde buğday, arpa, çavdar ve yulaf gibi tahıllardaki glutene karşı yaşam boyu intolerans ile karakterize immün aracılı bir hastalıktır (13). Çölyak hastalığına gluten, genetik ve çevresel etmenler arasındaki etkileşim neden olmaktadır. Anne sütü/formula ile beslenme, emzirme süresi, glutene başlama zamanı/miktarı, yenidoğan döneminde geçirilen enfeksiyonlar gibi çevresel etmenlerin çölyak patogenezinde rol oynadığı düşünülmektedir. Bu etmenlerin aynı zamanda bağırsak mikrobiyotasının bileşimini de etkilediği düşünüldüğünde, bağışıklık sisteminin ve oral toleransın uygun şekilde gelişiminde mikrobiyotanın rolü ortaya çıkmaktadır (14). Çölyak hastası çocukları sağlıklı kontrollerle karşılaştıran çalışmada fekal mikrobiyal bileşim ve mikrobiyal çeşitlilikte farklılıklar gözlenmiştir (15). Çölyak hastalarında, sağlıklı bireylere göre yararlı türlerde (Lactobacillus ve Bifidobacterium) azalma ve potansiyel olarak patojen olanlarda (Bacteroides ve E. coli) artış meydana gelmiştir (15).

Glutensiz diyet, çölyak hastalığında klinik semptomların ve komplikasyonlarının remisyonu için tek tedavidir. Glutensiz diyet hastalığın tedavisinde etkili ve güvenli olmasına rağmen, bağırsak mikrobiyotası ile ilişkili disbiyozis durumunu normalleştirmede tam olarak etkili olamadığı düşünülmektedir (13). Çölyak hastalığında glutensiz beslenmenin bağırsak mikrobiyotasına etkisini araştıran çalışmada, glutensiz diyet sonrası E. coli ve Staphylococcus gibi bazı potansiyel patojen bakterilerin bollukları azalmış olsa da, Bifidobacterium ve Lactobacillus gibi yararlı türlerin de düşük düzeyde kaldığı gösterilmiştir (16). Çölyak hastası çocuklarda glutensiz diyetten önce ve sonra fekal mikrobiyotanın sağlıklı kontrollerle karşılaştırıldığı bir çalışmada, glutensiz diyetle tedaviden sonra Lactobacillus topluluğunun çeşitliliği iki grupta benzerken, sağlıklı kontrollere kıyasla çölyaklı çocuklarda Bifidobacterium'un Bacteroides ve Enterobakteriler'e oranının daha düşük olduğu saptanmıştır (17). Bu bulgular, mikrobiyotadaki disbiyozisin, glutensiz bir diyete başlandıktan sonra bile tam olarak düzelmediğini göstermektedir.

Gluten içeren tahıl kaynaklarının çıkarılmasıyla bağırsak mikrobiyatasında yaşayan yararlı bakterilere besin kaynağı olan prebiyotiklerin azalması, bağırsak mikrobiyotası üzerindeki olumsuz etkilerin nedenini açıklayabilir (18). Bu nedenle glutensiz diyetin prebiyotik veya probiyotiklerle takviyesine yönelik ilgi artmaktadır. Klinik bir çalışmada çölyak hastalığı tanısı almış 34 çocuğa glutensiz diyet sırasında günde $10 \mathrm{~g}$ prebiyotik desteği verilmiş, üç aylık randomize kontrollü müdahaleden sonra prebiyotik grubunda Bifidobacterium sp. sayısında anlamlı bir artış olduğu gösterilmiştir (18). Prebiyotik grubunda ayrıca toplam fekal KZYA düzeyinin, plasebo grubundan anlamlı olarak daha yüksek olduğu bildirilmiştir. Çalışma bulguları, glutensiz diyet sırasında bağırsak mikrobiyotasının prebiyotiklerle desteklenmesinin umut verici bir yaklaşım olabileceğini göstermektedir (18). Başka bir çalışmada glutensiz diyetle beslenen, çölyak hastası 109 çocuğa altı haftalık probiyotik verilmesi sonrası, probiyotik karışımının semptomların iyileştirilmesinde etkili olduğu gösterilmiştir (19). Probiyotik desteği alanlarda laktik asit bakterileri ve Bifidobacterium düzeyleri artmıştır. $\mathrm{Bu}$ bulgular umut verici olmakla birlikte çölyak hastalığında probiyotik kullanımı konusunda öneride bulunabilmek için daha fazla klinik araştırmaya gerek vardır. 
Diyetisyenler tarafindan beslenme planı oluşturulurken posa içeriği yüksek olan glutensiz özel ürünlerin veya glutensiz alternatif tahılların/ tohumların seçilmesi, prebiyotik etki açısından sağlıklı bağırsak mikrobiyotasının gelişimi için daha uygun olabilir (18). Bu doğrultuda gelecekteki çalışmalarda işlenmiş glutensiz ürünlere klyasla amarant, kinoa gibi posa içeriği yüksek alternatif tahıl/tohum kaynaklarına diyette daha fazla yer verilmesinin bağırsak mikrobiyotası üzerindeki etkilerinin araştırılması yararlı olacaktır. Ayrıca Türkiye'de glutensiz ürünler üreten ulusal firmaların sayısı artırılmalı ve posa eklenmiş, besin ögesi içeriği daha kaliteli ürünler üretilmelidir. Ailelerin bu ürünlere ulaşılabilirliğini artırmaya yönelik düzenlemeler yapılmalıdır.

\section{Kistik Fibrozis}

Kistik fibrozis (KF), kistik fibrozis transmembran regülatör (KFTR) proteinini kodlayan gendeki mutasyonun neden olduğu otozomal resesif geçişli bir hastalıktır (20). Klor ve bikarbonat salgılanmasına aracılık eden KFTR proteinindeki mutasyon, epitel membran boyunca mukus salgisının artmasina neden olmaktadır. Kalınlaşmış mukus bakterilerin kolonizasyonu ve kronik inflamasyonun gelişimi için ideal bir ortam oluşmasına yol açmaktadır (20). KF hastalarınınfekalörneklerindeEnterobacteriaceae'nin daha yüksek olduğu, buna karşllık Bifidobacterium ve Clostridium küme XIVa üyelerinin düzeyinin önemli derecede düşük olduğu gösterilmiştir (21). KF hastalarında disbiyozis oluşumuna katkıda bulunabilecek diğer etmenler hastalığın yönetiminde yaygın olarak kullanılan antibiyotikler ve yüksek yağlı diyetlerdir (20).

Yüksek yağ ve yüksek enerji alımı KF’nin tıbbi beslenme tedavisinde yaygin olarak önerilmektedir (22). Diyet yağının Bacteroidetes kaynaklı lipopolisakkarit (LPS) yoluyla bağırsak geçirgenliğini arttırdığı gösterilmiştir (23). KF popülasyonunda

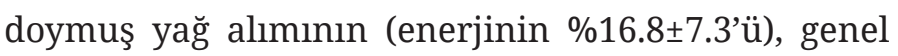
popülasyon için önerilenden (enerjinin <\%10) daha yüksek olduğu görülmektedir (24). KF’li hastalarda görülen artan doymuş yağ alımı, proinflamatuvar sitokin üretimini ve kronik inflamasyonu artırarak inflamasyonu şiddetlendirebilir (23). Bu nedenle çoklu doymamış yağ asitlerini (özellikle de antiinflamatuvar olan omega-3 yağ asitlerini) doymuş yağ asitlerine göre daha fazla içeren yüksek yağll, yüksek enerjili diyetin mikrobiyota üzerindeki etkisini değerlendirecek çalışmalar gereklidir. KF'de sindirilmeyen karbonhidratların diyetteki içeriğinin arttırılmasının uygulanabilirliği ve etkinliğinin incelenmesi bağırsak mikrobiyotasının modülasyonu için faydalı olabilir (23). KF'li bireylerde diyet bileşenleri ile bağırsak mikrobiyotası arasındaki ilişkinin araştırılması ve tıbbi beslenme tedavisi yoluyla modülasyonu, KF ile ilişkili komplikasyonlar ve komorbiditelerin iyileştirilebilmesi için uygun bir adım olacaktır.

\section{Obezite}

Bağırsak mikrobiyotasının vücut ağırlığının ve enerji homeostazının kontrolünde rol oynayarak obezitenin patofizyolojisinde yer aldığı düşünülmektedir (25). Bağırsak mikrobiyotası ile obezite gelişimi arasındaki ilişkiyi açıklamak için farklı mekanizmalar ortaya konulmuştur. İlk mekanizma, bağırsak bakterilerinin sindirilemeyen karbonhidratlardan enerji elde etmedeki rolüyle ilgilidir ve konakçıya ek bir enerji kaynağı sağlamaktadır. İkincisi, bağırsak bakterilerinin kandaki LPS düzeylerini modüle etme kabiliyeti sonucu obeziteye neden olan orta derecede sistemik inflamasyon başlangıcının tetiklenmesidir. Üçüncü mekanizma, bağırsak mikrobiyotasının enerji metabolizmasına katkıda bulunmasına dayanmaktadır(26).İnsançalışmalarında, obezvezayıf bireyler arasındaki bağırsak mikrobiyota bileşiminde farklılıklar gösterilmiştir (25). $\mathrm{Bu}$ farklılıklar çoğunlukla Firmicutes filumu ve Bacteroidetes düzeyinde saptanmıştır. Yedi araştırmanın sistematik derlemesinde (n=1707), Firmicutes ve Bacteroidetes türü düzeylerindeki değişikliklerin çocukluk çağ obezitesi için önemli göstergeler olabileceği, ancak makale sayıları ve değerlendirilen araştırmalardaki heterojenlik dikkate alındığında daha iyi tasarlanmış 
çalışmalara ihtiyaç olduğu belirtilmiştir (26).

Çocukluk çağı obezitesinde beslenme tedavisi kapsamında sağlıklı beslenme alışkanlıklarının kazandırılması enerji alımı ile birlikte bağırsak mikrobiyota bileşimi üzerinde de önemli bir etkiye sahiptir (27). Obez bir adölesan popülasyonunda enerji kısıtlı diyete ve artmış fiziksel aktiviteye dayalı bir vücut ağırlık kaybı programının, Clostridium histolyticum ve Eubacterium rectale-Clostridium coccoides oranlarında azalmaya neden olduğu ve bu azalmanın vücut ağırlık kaybı ve beden kütle indeksi (BKİ)z-skorunda azalmaileilişkiliolduğu gösterilmiştir (28). Tam tahillar, meyve, sebze ve baklagillerin daha yüksek olduğu beslenme planının çeşitli mikrobiyal popülasyonları desteklediği, koruyucu türlerin miktarını artırdığı, patojen türlerin miktarını ve inflamatuvar etmenleri azalttığı belirtilmiştir (27). Günlük posa alımının 25-38 g yükseltilmesi (en az 5-20 g prebiyotik kaynaklar içeren) KZYA'ların üretimini artırabilir, bağırsak bariyer işlevini iyileştirebilir, vücut ağırlığını azaltmaya yardımcı olabilir. Bu değişikliklere diyet kaynaklı olarak Lactobacillus, Bifidobacterium ve Prevotella'daki artışların aracılık ettiği düşünülmektedir (27). Özetle çocukluk çağ obezitesinde tıbbi beslenme tedavisi kapsamındaki öneriler bağırsak mikrobiyotasını olumlu yönde etkilemektedir.

\section{Tip 1 Diyabet}

Tip 1 diyabet (T1D), pankreasın insülin salgllayan $\beta$ hücresinin harabiyeti ile insülin üretme kabiliyetini yitirmesi sonucu meydana gelen otoimmün bir hastalıktır (29). Doğum şekli, diyet, enfeksiyonlar ve antibiyotik kullanımı gibi çevresel etmenler genetiğe ek olarak T1D gelişimi ile ilişkilendirilmiştir. Bağırsak mikrobiyotasının çevresel etmenler ile otoimmünite ve T1D gelişimi arasındaki bağlantı olabileceği düşünülmektedir (29). Bağırsak mikrobiyotasındaki değişiklikler sonucunda oluşan bağırsak geçirgenliğinde artış ve disbiyozis, immün düzenleyici mekanizmalarda bozulmayı ve pankreasın $\beta$ hücrelerinde harabiyet ile sonuçlanan otoimmün süreci tetikleyebilmektedir (30). Yapılan bir çalışmada Bacteroides, T1D ile ilişkili disbiyozise yol açan ana cins olarak saptanmıştır (31). İki veya daha fazla adacık otoantikorlu çocuklarda Bifidobacterium cinslerinin bulunmadığı ve Bacteroides düzeylerinin arttığı bildirilmiştir (31). Ayrıca T1D’li hastalar sağlıklı kontrollere kıyasla daha az farklı ve daha az kararlı bağırsak mikrobiyota bileşimi sergilemektedir ve hastalarda Firmicutes'in Bacteroidetes'e oranında azalma olduğu gözlenmiştir (30). Bozulmuş bağırsak geçirgenliğinin T1D gelişiminin bir nedeni mi yoksa bir sonucu mu olduğu ise henüz netleştirilmemiştir.

Tip 1 diyabetin tubbi beslenme tedavisi bireyin cinsiyetine ve yaşına uygun olarak enerji ve yeterli miktarda karbonhidrat, protein, yağ, vitaminmineraller ile posa içermelidir. Akdeniz tipi beslenme modeli, Amerikan Diyabet Derneği tarafından belirtildiği gibi sağlıklı beslenmeye uygun bir beslenme modelidir (32). Akdeniz tipi beslenme fekal KZYA'ların ve Lactobacillus, Bifidobacterium ve Prevotella düzeylerinin artmasıyla ilişkilendirilmiştir (33). Probiyotik Lactobacillus rhamnosus GG ve Bifidobacterium lactis Bb12 desteğinin T1D'li çocuklarda, bağırsak mikrobiyotasında oluşan dengesizlikleri düzenlediği ve pankreas $\beta$ hücrelerinin sayısını koruduğu gösterilmiştir (29). Prebiyotik desteğinin 8-17 yaşları arasındaki T1D’li çocukta glisemik kontrole etkisinin incelendiği çalışmada, prebiyotik grupta hemoglobin A1c'de anlaml bir azalma görülmezken, C-peptid seviyesinde plasebo grubuna kıyasla bir artış olduğu gösterilmiştir (34). Araştırmacılar, bunun glisemik kontrolün iyileşmesini sağlayacak $\beta$-hücre fonksiyonu gelişimi için önemli olabileceğini belirtmiştir (34).

Diyabetli bireylerde mikrobiyotanın modüle edilmesine yönelik spesifik beslenme önerilerinde bulunmak için daha fazla araştırmaya gerek vardır. Mevcut veriler, enerji ve besin ögesi gereksiniminin yeterli ve dengeli beslenmeyi sağlayacak biçimde çeşitli besinlerden karşılanmasına işaret etmektedir. Genel olarak, bir besin ögesi/grubunu hariç tutan kısıtlayıcı diyetlerden çok, tüm besin ögelerini/ gruplarını içeren ve çeşitliliğin sağlandığı beslenme tedavileri, bağırsak bakterilerinin çeşitliliğini şekillendirecektir. 


\section{Fenilketonüri}

Fenilketonüri (FKÜ) fenilalanin hidroksilaz (FAH) enzimindeki mutasyonun neden olduğu fenilalanin metabolizmasının otozomal resesif geçişli kalıtsal metabolik bir bozukluğudur (35). Monogenik hastalık olmasına rağmen tek başına genotip bu hastalarda gözlenen fenotipteki geniş değişkenliği açıklamak için yeterli değildir. Genetik ve diyet, mikrobiyota üzerinde güçlü bir etkiye sahiptir (36). FKÜ hastalarının mikrobiyotasının incelenmesi, hem fenotip anlayışı ilerleten hem de yeni biyobelirteçlerin ve tedavilerin gelişimine yönelik klinik uygulamalar için veri sağlayabilir.

FKÜ hastalığında tıbbi beslenme tedavisi, fenilalanin alımının kısitlanmasına dayanmaktadır (35). Son zamanlarda yapılan birkaç çalışmada, fenilalanin kısıtlı diyetin bağırsak mikrobiyota bileşimini değiştirebileceği ve bağırsak homeostazını etkileyebileceği gösterilmiştir (37,38). Fenilalanin kısıtlı diyet tedavisi alan 8 hastanın mikrobiyotası 10 sağlıklı birey ile karşılaştırılmıştır (37). FKÜ hastalarında Prevotella ve Akkermansia bolluğunun arttığ1; Erysipelotrichaceae ve Lachnospiraceae, Ruminococcus ve Veillonella familyalarında bakteri bolluğunun azaldığı gösterilmiştir. Fenilalanin kısıtlı diyet uygulayan FKÜ'lü $(n=21)$ ve kısıtlı bir diyet uygulamayan hafif hiperfenilalaninemili çocuklarda (n=21) yapılan bir çalışmada, FKÜ’lü çocuklarda hafif hiperfenilalaninemili çocuklara kıyasla mikrobiyal çeşitliliğin ve fekal bütirat içeriğinin daha düşük olduğu bulunmuştur (38). FKÜ grubunda karbonhidrat, lif ve sebze alımı daha fazla olmasına rağmen bütirat üreticileri olan Faecalibacterium prausnitzii ve Roseburia spp. türlerinde tükenme olduğu gösterilmiştir. Bağırsak mikrobiyotasında meydana gelen bu değişikliklerin FKÜ'nün bir etkisi mi veya düşük fenilalaninli diyetin sonucu mu olduğu belirsizliğini korumaktadır.

FKÜ’lü hastalarda bağırsak mikrobiyotasını sağlıklı çocuklara benzetmek için farklı yaklaşımlar uygulanmaktadır. FKÜ'lü bireylerde prebiyotiklerin etkisini inceleyen MacDonald ve ark. (39) prebiyotik eklenmiş aminoasit karışımının dolaşımdaki fenilalanin düzeylerini değiştirmeden bifidobakteri düzeylerini ve düşük fekal pH’yı koruyabildiğini bulmuştur. Küçük örneklem büyüklüğüne ve istatistiksel güç eksikliğine rağmen, bu bulgu prebiyotik eklenmiş aminoasit karışımlarının FKÜ için bir strateji olabileceğini düşündürmektedir.

FKÜ’lü çocuklarda bağırsak mikrobiyotasının ve fenilalanin kısıtlı diyet tarafından değişen mikrobiyal türlerin anlaşılması ve fenilalanin kısıtlı diyetle birlikte pre/probiyotik desteklerinin etkileri için daha fazla araştırmaya gerek vardır. Uzun süreli sağlık üzerine etkileri göz önüne alındığında, sağlıklı ve çeşitli bir bağırsak mikrobiyotasının oluşturulması için FKÜ'lü bireylerin yaşamlarını iyileştirebilecek beslenme ürünlerinin geliştirilmesi gerekmektedir. FKÜ’lü bireylerin bağırsak mikrobiyotasını anlamak, mikrobiyotayı destekleyebilecek ürünlerin geliştirilmesine rehberlik edebilir.

\section{Epilepsi}

Epilepsi, çeşitli nedenlerle merkezi sinir sisteminde ortaya çıkan anormal elektriksel deşarjlar sonucu meydana gelen geçici serebral fonksiyon bozukluğudur (40). Bağırsak mikrobiyotası, bağırsak-beyin ekseni üzerinden çeşitli nörolojik bozukluklarla ilişkilendirilmiştir. Bağırsak mikrobiyotasındaki bozulmalarm beynin uyarılabilirliğini değiștirebileceği ve epileptik nöbetleri tetikleyebileceği öne sürülmektedir (40).

Ketojenik diyet (KD), dirençli epilepsili çocuklarda kullanılan farmakolojik olmayan bir tedavidir. Yüksek yağ, yeterli protein, düşük karbonhidrat içeren bir beslenme modelidir. Klasik KD’nin, yağ miktarında belirgin bir artışın ve karbonhidrat miktarında azalışın etkisiyle epilepsi hastalarında bağırsak mikrobiyotasının çeşitliliğini ve zenginliğini azaltabildiği gösterilmiştir (40). Dirençli epilepsili çocuklarda KD’nin bağırsak mikrobiyotasına etkisinin incelendiği iki çalışmada mikrobiyal çeşitlilik, Firmicutes ve Actinobacteria miktarında azalış, Bacteroidetes ve $E$. coli'de artış olduğu bulunmuştur 
$(40,41)$. KD’nin bağırsak ortamını olumsuz yönde etkileyebileceği görülmektedir. Bu bulgular, ketojenik diyetin uzun vadeli güvenliğini araştıran, daha büyük kohort çalışmalara olan ihtiyacı vurgulamaktadır.

Ketojenik diyet, lifiçeriği düşük bir beslenme modelidir ve bu doğrultuda KD sırasında epilepsi hastalarında, bifidobakterilergibiliftüketenbakterilerinbolluğunun azaldığı görülmektedir (41). Diyetisyenler bağırsak bakterileri tarafından kullanılan lifleri içerecek şekilde KD’leri düzenleyebilir. Prebiyotik özellikteki inulin, laktuloz, frukto-oligosakaritler ve galaktooligosakaritlerin, tercihen bifidobakterileri arttırdığı ve $E$. coli ve enterokokları azalttığı bilinmektedir (42). Ketojenik diyetin klasik, düşük glisemik indeksli ve orta zincirli trigliserit içeren şeklinde türlerinin içeriklerindeki farklılıklardan dolayı mikrobiyota üzerine olan etkilerinin de farklı olması beklenebilir. Ayrıca KD’deki yüksek miktardaki diyet yağının kaynağı da bağırsak mikrobiyotasındaki değişiklikleri etkileyebilir. Farklı yağ çeşitlerinin (tekli doymamış yağ asitleri, doymuş yağ asitleri ve çoklu doymamış yağ asitleri) bağırsak mikrobiyota bileşimi üzerindeki etkisinin araştırıldığı çalışmada, doymuş yağ asidinin yüksek olduğu diyet, Firmicutes-Bacteroidetes oranını arttırmış ve mikrobiyota çeşitliliğini azaltılmıştır (43). Yüksek tekli doymamış yağ asidi (zeytinyağı) veya çoklu doymamış yağ asitleri (aspir yağı) ile beslenen farelerde mikrobiyotada belirgin bir kayma olmamıştır. Bu çalışma, bağırsak mikrobiyotasının doymuş ve doymamış yağlardan farklı şekilde etkilendiğini göstermektedir. $\mathrm{Bu}$ bulguların insan çalışmaları ile doğrulanması, KD sırasında hastaların bağırsak mikrobiyotasındaki istenmeyen değişiklikleri önleyebilmek adına diyetisyenler için önemli olacaktır.

\section{SONUÇ VE ÖNERILER}

Beslenme, bağırsak mikrobiyota bileşimini etkileyen etmenlerin en önemlilerinden biri olarak görülmektedir. Mevcut veriler, bağırsak mikrobiyota bileşiminin korunması ve iyileştirilmesinde diyet ve makro besin ögeleri içeriğinin önemli olduğunu ve yeterli miktarda ve sağlıklı kaynaklardan karbonhidrat ve posa alımının sağlanması gerektiğini göstermektedir. Belirli bir besin grubu ve besin ögesinin kısıtlandığı tıbbi beslenme tedavilerinin de bağırsak mikrobioyatası üzerinde etkileri olabileceği unutulmamalıdır. Bağırsak mikrobiyotasının hastalıkların oluşumunda ve yönetimindeki etkilerine yönelik literatürdeki ilerlemeler, beslenme tedavileri planlanırken mikrobiyota odaklı yaklaşımların geliştirilmesineyardımcıolacaktır. Buaçıdan belirlibir tıbbi beslenme tedavisi altındaki bireylerin disbiyozis durumlarının tanımlanması, diyetisyenlerin hastalar için bireyselleştirilmiş beslenme müdahaleleri geliştirebilmeleri için gereklidir. Hastalıklarda uygulanan beslenme tedavilerinin probiyotik ve prebiyotiklerle desteklenmesi bağırsak mikrobiyota dengesizliklerini önleyebilir. Ancak bu görüşün desteklenmesi için daha fazla araştırılmaya ihtiyaç vardır.

Çıkar çatışması - Conflict of interest: Yazarlar çıkar çatışması olmadığını beyan ederler. - The authors declare that they have no conflict of interest.

\section{KAYNAKLAR}

1. Young VB. The role of the microbiome in human health and disease: an introduction for clinicians. BMJ. 2017;356:j831.

2. Reddel S, Putignani L, Del Chierico F. The Impact of Low-FODMAPs, Gluten-Free, and ketogenic diets on gut microbiota modulation in pathological conditions. Nutrients. 2019;11(2):373-89.

3. Canani RB, Paparo L, Nocerino R, Di Scala C, Della Gatta G, Maddalena Y, et al. Gut microbiome as target for innovative strategies against food allergy. Front Immunol. 2019;10:191.

4. Johnson CC, Ownby DR. The infant gut bacterial microbiota and risk of pediatric asthma and allergic diseases. Transl Res. 2017;179:60-70.

5. Grimshaw KE, Maskell J, Oliver EM, Morris RC, et al. Diet and food allergy development during infancy: birth cohort study findings using prospective food diary data. J Allergy Clin Immunol. 2014;133(2):511-9.

6. Tan J, McKenzie C, Vuillermin PJ, Goverse G, Vinuesa CG, et al. Dietary fiber and bacterial SCFA enhance oral tolerance and protect against food allergy through diverse cellular pathways. Cell Rep. 2016;15(12):2809-24. 
7. Sicherer, SH. Clinical aspects of gastrointestinal food allergy in childhood. Pediatrics. 2003;111(3):1609-16.

8. Gross G, Boer PD, Bobeldijk-Pastorova I, Ouwens A, Tol Ev, Keijser B. Infant gut microbiota composition and metabolism can be influenced by extensively hydrolyzed casein in vitro. FASEB J. 2015;29(1_supplement):914.1.

9. Brown K, DeCoffe D, Molcan E, Gibson DL. Diet-induced dysbiosis of the intestinal microbiota and the effects on immunity and disease. Nutrients. 2012;4(8):1095-119.

10. Schwiertz A, Jacobi M, Frick JS, Richter M, Rusch K, Kohler H. Microbiota in pediatric inflammatory bowel disease. J Pediatr. 2010;157(2):240-4.

11. Miele E, Shamir R, Aloi M, Assa A, Braegger C, Bronsky $\mathrm{J}$, et al. Nutrition in Paediatric Inflammatory Bowel Disease: A Position Paper on Behalf of The Porto IBD Group of ESPGHAN. J Pediatr Gastroenterol Nutr. 2018;66(4):687-708.

12. Gerasimidis K, Bertz M, Hanske L, Junick J, Biskou O, Aguilera M, et al. Decline in presumptively protective gut bacterial species and metabolites are paradoxically associated with disease improvement in pediatric Crohn's disease during enteral nutrition. Inflamm Bowel Dis. 2014;20(5):861-71.

13. Nylund L, Kaukinen K, Lindfors K. The microbiota as a component of the celiac disease and non-celiac gluten sensitivity. Clin Nutr Exp. 2016;6:17-24.

14. Sanz Y, Palma GD, Laparra M. Unraveling the ties between celiac disease and intestinal microbiota. Int Rev Immunol. 2011;30(4):207-18.

15. Nadal I, Donat E, Ribes-Koninckx C, Calabuig M, Sanz Y. Imbalance in the composition of the duodenal microbiota of children with coeliac disease. J Med Microbiol. 2007;56(12):1669-74.

16. Collado MC, Donat E, Ribes-Koninckx C, Calabuig M, Sanz Y. Specific duodenal and faecal bacterial groups associated with paediatric coeliac disease. J Clin Pathol. 2009;62:264-9.

17. Di Cagno R, Rizzello CG, Gagliardi F, Ricciuti P, Ndagijimana M, Francavilla R, et al. Different fecal microbiotas and volatile organic compounds in treated and untreated children with celiac disease. J Appl Environ Microbiol. 2009;75(12):3963-71.

18. Drabinska N, Jarocka-Cyrta E, Markiewicz LH, KrupaKozak U. The effect of oligofructose-enriched inulin on faecal bacterial counts and microbiota-associated characteristics in celiac disease children following a gluten-free diet: results of a randomized, placebocontrolled trial. Nutrients. 2018;10(2):201-2.

19. Francavilla R, Piccolo M, Francavilla A, Polimeno L, Semeraro F, Cristofori F, et al. Clinical and microbiological effect of a multispecies probiotic supplementation in celiac patients with persistent ıbs- type symptoms: a randomized, double-blind, placebocontrolled, multicenter trial. Clin J Gastroenterol. 2019;53(3):e117-e25.

20. Dorsey J, Gonska T. Bacterial overgrowth, dysbiosis, inflammation, and dysmotility in the Cystic Fibrosis intestine. J Cyst Fibros. 2017;16 Suppl 2:S14-S23.

21. Duytschaever G, Huys G, Bekaert M, Boulanger L, De Boeck K, Vandamme P. Dysbiosis of bifidobacteria and Clostridium cluster XIVa in the cystic fibrosis fecal microbiota. J Cyst Fibros. 2013;12(3):206-15.

22. Stallings VA, Stark LJ, Robinson KA, Feranchak AP, Quinton H. Evidencebased practice recommendations for nutrition-related management of children and adults with cystic fibrosis and pancreatic insufficiency: results of a systematic review. J Am Diet Assoc. 2008;108:832-9.

23. Li L, Somerset S. The clinical significance of the gut microbiota in cystic fibrosis and the potential for dietary therapies. Clin Nutr. 2014;33(4):571-80.

24. Gordon CM, Anderson EJ, Herlyn K, Hubbard JL, Pizzo A, Gelbard R, et al. Nutrient status of adults with cystic fibrosis. J Am Diet Assoc. 2007;107(12):2114-9.

25. Bervoets L, Van Hoorenbeeck K, Kortleven I, Van Noten C, Hens N, Vael C, et al. Differences in gut microbiota composition between obese and lean children: a crosssectional study. Gut Pathog. 2013;5(1):101-11.

26. Indiani CMDSP, Rizzardi KF, Castelo PM, Ferraz LFC, Darrieux Parisotto TM. Childhood Obesity and Firmicutes/Bacteroidetes Ratio in the Gut Microbiota: A Systematic Review. Child Obes. 2018;14(8):501-9.

27. Lopez-Legarrea P, Fuller NR, Zulet MA, Martinez JA, Caterson ID. The influence of Mediterranean, carbohydrate and high protein diets on gut microbiota composition in the treatment of obesity and associated inflammatory state. Asia Pac J Clin Nutr. 2014;23(3):3608.

28. Nadal I, Santacruz A, Marcos A, Warnberg J, Garagorri JM, Moreno LA, et al. Shifts in clostridia, bacteroides and immunoglobulin-coating fecal bacteria associated with weight loss in obese adolescents. Int J Obes (Lond). 2009;33(7):758-67.

29. Groele L, Szajewska H, Szypowska A. Effects of Lactobacillus rhamnosus GG and Bifidobacterium lactis Bb12 on beta-cell function in children with newly diagnosed type 1 diabetes: protocol of a randomised controlled trial. BMJ Open. 2017;7(10):e017178.

30. Gulden E, Wong FS, Wen L. The gut microbiota and Type 1 Diabetes. Clin Immunol. 2015;159(2):143-53.

31. de Goffau MC, Fuentes S, van den Bogert B, Honkanen H, de Vos WM, Welling GW, et al. Aberrant gut microbiota composition at the onset of type 1 diabetes in young children. Diabetologia. 2014;57(8):1569-77.

32. Association AD. 5. Lifestyle management: standards 
of medical care in diabetes-2019. Diabetes Care. 2019;42(Supplement 1):S46-S60.

33. Jardine M. Nutrition considerations for microbiota health in diabetes. Diabetes Spectr. 2016;29(4):238-44.

34. Ho J, Nicolucci AC, Virtanen H, Schick A, Meddings J, Reimer RA, et al. Effect of prebiotic on microbiota, intestinal permeability and glycemic control in children with type 1 diabetes. J Clin Endocrinol Metab. 2019;104(10):4427-40.

35. van Wegberg AMJ, MacDonald A, Ahring K, BélangerQuintana A, Blau N, Bosch AM, et al. The complete European guidelines on phenylketonuria: diagnosis and treatment. Orphanet J Rare Dis. 2017;12(1):162-218.

36. Colonetti K, Roesch LF, Schwartz IVD. The microbiome and inborn errors of metabolism: Why we should look carefully at their interplay? Genet Mol Biol. 2018;41(3):515-32.

37. Pinheiro de Oliveira F, Mendes RH, Dobbler PT, Mai V, Pylro VS, Waugh SG, et al. Phenylketonuria and gut microbiota: a controlled study based on next-generation sequencing. PloS One. 2016;11(6):e0157513.

38. Verduci E, Moretti F, Bassanini G, Banderali G, Rovelli V, Casiraghi MC, et al. Phenylketonuric diet negatively impacts on butyrate production. Nutr Metab Cardiovasc
Dis. 2018;28(4):385-92.

39. MacDonald A, Cochrane B, Wopereis H, Loveridge N. Specific prebiotics in a formula for infants with Phenylketonuria. Mol Genet Metab. 2011;104 Suppl:S55-9.

40. Zhang Y, Zhou S, Zhou Y, Yu L, Zhang L, Wang Y. Altered gut microbiome composition in children with refractory epilepsy after ketogenic diet. Epilepsy Res. 2018;145:1638.

41. Lindefeldt M, Eng A, Darban H, Bjerkner A, Zetterström $\mathrm{CK}$, Allander $\mathrm{T}$, et al. The ketogenic diet influences taxonomic and functional composition of the gut microbiota in children with severe epilepsy. NPJ Biofilms Microbiomes. 2019;5(1):5-18.

42. Wilson B, Whelan K. Prebiotic inulin-type fructans and galacto-oligosaccharides: definition, specificity, function, and application in gastrointestinal disorders. J Gastroenterol Hepatol. 2017;32(S1):64-8.

43. de Wit N, Derrien M, Bosch-Vermeulen H, Oosterink E, Keshtkar S, Duval C, et al. Saturated fat stimulates obesity and hepatic steatosis and affects gut microbiota composition by an enhanced overflow of dietary fat to the distal intestine. Am J Physiol Gastrointest Liver Physiol. 2012;303(5):G589-99. 